$$
\begin{aligned}
& \text { The Stockholm University } \\
& \text { Linnaeus Center for } \\
& \text { Integration Studies (SULCIS) }
\end{aligned}
$$

\title{
National Identity and Support for the Welfare State
}

Richard Johnston, Keith Banting, Will Kymlicka and Stuart Soroka

Working Paper 2010:11

ISSN 1654-1189 


\title{
NATIONAL IDENTITY AND SUPPORT FOR THE WELFARE STATE
}

\author{
Richard Johnston, University of British Columbia (rjohnston@ politics.ubc.ca) \\ Keith Banting, Queen's University (keith.banting@queensu.ca) \\ Will Kymlicka, Queen’s University (kymlicka@queensu.ca) \\ Stuart Soroka, McGill University (stuart.soroka@mcgill.ca)
}

Abstract: This paper examines the role of national identity in sustaining public support for the welfare state. Liberal nationalist theorists argue that social justice will always be easier to achieve in states with strong national identities which, they contend, can both mitigate opposition to redistribution among high-income earners and reduce any corroding effects of ethnic diversity resulting from immigration. We test these propositions with Canadian data from the Equality, Security and Community survey. We conclude that national identity does increase support for the welfare state among affluent majority Canadians, and that it helps to protect the welfare state from toxic effects of cultural suspicion. However, we also find that identity plays a narrower role than existing theories of liberal nationalism suggest, and that the mechanisms through which it works are different. This leads us to suggest an alternative theory of the relationship between national identity and the welfare state, one that suggests that the relationship is highly contingent, reflecting distinctive features of the history and national narratives of each country. National identity may not have any general tendency to strengthen support for redistribution, but it may do so for those aspects of the welfare state seen as having played a particularly important role in building the nation, or in enabling it to overcome particular challenges or crises. 
The contemporary era is marked by growing inequality. A recent OECD study of 30 developed countries documents a pervasive increase in inequality that has been gathering momentum since at least the mid-1980s. It also demonstrates that the redistributive impact of governments has been weakening since the mid-1990s, as benefits have become less targeted on the poor (OECD 2008). These trends have triggered an anxious debate about why the redistributive state seems to be fading. Some commentators see growing resistance in terms of the intensification of economic interests, as more affluent voters stiffen their opposition to sharing with the poor. Others point to cultural changes, as new patterns of ethnic diversity resulting weaken social solidarity.

In this context, what are the bulwarks of mutual commitment and solidarity in contemporary societies? What are the mechanisms by which a sense of solidarity is enhanced or diminished? What attitudes can offset any corrosive effects generated by economic interest or cultural suspicion? Various answers have been given to these questions. But one argument that has gained attention in recent years is that a strong sense of national identity can sustain a sense of community, one defined by a shared commitment to mutual support. Traditionally, nationalism has been seen as a powerful but potentially exclusionary force in history, the source of conflict and oppression as much as of solidarity. But for contemporary liberal nationalists, national identity offers social glue, one which is potentially inclusive and capable of binding people otherwise divided by economic and ethnic differences into a sharing community.

This paper examines the role of national identity in sustaining support for the welfare state in Canada. It seeks to answer two questions. First, does national identity mitigate opposition to the welfare state and redistribution among high-income Canadians? Second, does national identity mitigate any corrosive effects that the ethnic diversity flowing from new patterns of 
immigration may have on the support for redistribution? The paper answers these questions in the affirmative. In short, it argues that national identity contributes to a sense of belonging and solidarity that transcends economic interest and cultural difference. The forms of the relations differ in the two cases, and are not always consistent with the mechanisms suggested by theorists in the field. But the relationships matter.

The paper develops the analysis in four sections. First, we position the study in the context of existing theoretical discussions of the issues and summarize the limited empirical literature on the topic. Then we present Canada as a test case for many of these issues, and describe the data on which the analysis draws. Following this are the results of our analyses. We conclude by reflecting on their wider significance.

\section{EXISTING RESEARCH}

This study situates itself in two relatively distinct approaches to the welfare state, one which bases the analysis primarily on the foundation of economic interest, and another which explores the implications of ethnic diversity for social solidarity. In this section, we examine each literature separately and then explore theoretical ideas about the potential role of national identity in building support for the welfare state.

Economic interest and national identity: Students of redistribution have long rooted their analysis in the politics of economic interest. The first generation of the comparative welfare state literature highlighted the role of class alliances and the strength of organized labour (Stephens 1979, Korpi 1983, Esping-Anderson 1990). While recent contributions to this literature have broadened the range of factors, economic interest remains central to the tradition (Hicks 1999; Huber and Stephens 2001; Swank 2002). Similarly, analysts in the public choice tradition focus on the economic interests of the median voter in explaining the sources and limits of support for 
redistribution (Romer 1975; Meltzer and Richard 1981). While the analytical framework differs, the core assumption is the same: rich voters have an incentive to resist redistribution; poorer voters have an incentive to support it. Empirical support for this obvious assumption is ubiquitous. (For cross-national evidence, see Svallors 1997, 2003) Moreover, some analysts have argued that powerful forces are increasing the gap. For example, Reich (1991) argues that globalization and technological change have increased not only the income gap but also the political gap between highly skilled professionals and unskilled workers, as his "symbolic analysts" retreat physically and politically into gated communities.

What factors can help overcome this tendency for the rich to dissociate themselves, physically and emotionally, from the plight of the disadvantaged? An argument common to both public debate and academic writing emphasizes the importance of national identity that encompasses both rich and poor. A national identity is not just a passive fact about individuals, but is motivationally powerful, since it involves a sense of "ethical community". To share a sense of nationhood, on this view, is to accept a sense that we belong together in a community of shared fate, and have moral obligations to our co-nationals that go beyond mere humanitarianism.

A leading exponent of this view is the political theorist David Miller, who has argued that national identity is fundamental to sustaining a viable welfare state (Miller 1995, 1998). As he puts it, "Social justice will always be easier to achieve in states with strong national identities" (1995: 96). According to Miller, national identity plays a two-fold role. First it creates a sense of sympathy for co-nationals, which generates the initial motivation for concern for the disadvantaged. But equally importantly, it generates a sense of trust that is a precondition for individuals to act on their sympathy. Even those who feel a sense of sympathy for co-nationals 
will not act upon it if they are skeptical that their concern will be reciprocated. To secure the voluntary cooperation of citizens, "each person must be confident that the others will generally comply-and this involves mutual trust... ties of community are an important source of such trust between individuals who are not personally known to each other" (1995: 91-2). According to Miller, national identity is the essential basis for this trust in modern societies: "in states lacking a common national identity... trust may exist within the groups, but not across them" (1995: 92).

In a subsequent refinement, Miller argues that the role of national identity is especially important to those aspects of the welfare state that redistribute resources to the poor. A sense of solidarity is less critical to social programs that protect the population as a whole, as in the case of health care which largely redistributes resources from the healthy to the sick, or pensions which redistribute resources to those who live longest. "Self-interest alone will lead people to support welfare policies that insure them against the unpredictable hazards of various kinds" (Miller 2006: 328). However, policies that explicitly redistribute resources on a vertical basis to the poor, such as welfare and unemployment benefits, require that better-off people "identify with the beneficiaries of the redistribution — an identification fostered by a sense of common national identity" (ibid.).

Miller sees this relationship working largely though interpersonal trust (although he also concedes a secondary role for institutional trust ${ }^{\mathrm{i}}$ ). A common sense of national identity creates a sense of connectedness to each other that generates trust in one's co-nationals, enhancing the sense that they also see themselves as part of a moral community and share a commitment to the norm of reciprocity implicit in collective solidarity: "I take it as virtually self-evident that ties of community are an important source of such trust between individuals who are not personally known to one another and who are in no position directly to monitor one another's behaviour. A 
shared identity carries with it a shared loyalty, and this increases confidence that others will reciprocate one's own co-operative behaviour" (Miller 1995: 92).

A similar argument is made by Brian Barry, who argues that nationhood facilitates "redistribution within the polity" both by generating a sense of "fellow-feeling" and "sympathetic attachment to the interests" of co-nationals, and by generating a sense of "trust in the willingness of others to reciprocate benefits when the need arises" (Barry 1991: 174-7).

Versions of this argument have become a core strand in the school of thought known as "liberal nationalism." Against the widespread view that nationalism and liberalism are inherently at odds, liberal nationalists argue that nationhood is in fact a vital support for liberal democracy, by providing the sense of fellow-feeling and trust needed for a sustainable democratic welfare state (see also Tamir 1993; Canovan 1994; Rorty 1999; Goodhart 2004).

While this liberal nationalist position is now widespread, it is not without its critics (e.g., Abizadeh 2002), many of whom point out the lack of empirical evidence for the claim that national identity generates either interpersonal trust or support for redistribution. Indeed, very few studies have attempted to test this hypothesis, and those that do exist do not support the claims of liberal nationalists. One study of attitudes in Britain found no individual-level correlation between national identity and support for redistribution in Britain (Martinez-Herrera 2004); a more recent cross-national study found a negative relationship between national identity and support for redistribution across 26 democracies, at both the individual and aggregate levels (Shayo 2009). ${ }^{\text {ii }}$ The different results may be a product of quite different statistical approaches. Yet, as we discuss below, there are also different ways in which "national identity" can be defined and measured, and these are likely to be linked in different ways to support for the welfare state. Similarly, as Miller suggests, identity may be linked differently to different parts of 
the welfare state. So, much work remains to be done in theorizing and testing possible relationships between national identity and support for redistribution.

Ethnic diversity and national identity: Other commentators add immigration and growing ethnic diversity to the list of factors eroding the redistributive state. In this interpretation, immigration unsettles historic conceptions of community, which define those who are "us," recognized members of existing networks of rights and obligations, and those who are "strangers" or "others," whose needs seem less compelling. The growing presence of newcomers, especially ethnically distinct newcomers, is thus seen as eroding the sense of social solidarity on which welfare states are constructed. Ethnic diversity has not been central to the comparative literature on the welfare state. But advocates of this argument cite evidence from several sources. First, development economists increasingly point to ethnic and tribal diversity in attempting to explain the poor economic and social failures of a number of developing countries, especially in Africa (Easterly and Levine 1997; Easterly 2001a and 2001b; La Ferrara 2002, 2003; Nettle 2000; James 1987, 1993). Second, studies of the politics of social policy in the United States provide substantial evidence of racial diversity weakening redistribution. Racial conflict has clearly had a toxic impact on the politics of social policy throughout American history (Gilens 1999; Skocpol 1991; Quadagno 1988). In the contemporary era, Alesina, Baqir, and Easterly (2001) demonstrate that public spending tends to be lower in cities and states with higher levels of racial heterogeneity, and their results have been replicated by others (eg, Luttmer 2001). Alesina and Glaeser (2004) have recently extended this approach to cross-national differences. They conclude that almost half of the difference in social spending between the United States and European countries can be explained by differences in the level of racial diversity. 
This argument is also not without critics. While accepting that there is a potential conflict between ethnic diversity and solidarity, a number of authors have challenged the universality or inevitably of such tensions (Banting and Kymlicka 2006, Crepaz 2008; TaylorGooby 2005; Mau and Burkardt). They emphasize the need to understand the factors that mediate between diversity and redistribution, tipping the balance one way or the other in different countries.

Is national identity one of those factors? Many liberal nationalists, including David Miller, have suggested that a common sense of national identity can mediate the tensions here as well. Just as national identity can create empathy and trust between rich and poor, so it can create empathy and trust between native-born and newcomers, or between people of different ethnic, racial and religious backgrounds.

To be sure, there is an important asymmetry between the two cases. According to Miller, it is part of the very idea of nationhood that it encompasses different social classes, and hence connects rich and poor. But nationhood does not necessarily include immigrants or ethnic minorities. It is entirely possible to have an "ethnic" definition of the nation that excludes these very groups. And so liberal nationalists do not argue that people with a strong sense of national identity naturally or predictably are more empathetic or trusting of immigrants. A strong sense of national identity can, in some contexts, generate a feeling that immigrants are "others" who fall outside the bounds of the moral community that sustains solidarity. In such contexts, strong feelings of nationhood exacerbate the problem of diversity, not remedy it.

Miller and other liberal nationalists argue that this initial tendency to exclusion can be overcome if there are visible and tangible ways by which immigrants join the ethical community of the nation. This requires a two-fold approach: on the one hand, native-born citizens must be 
willing to allow newcomers to join the nation, and must provide avenues by which they can do so (and hence renounce ethnic or racial definitions of nationhood); on the other hand, newcomers must make a visible and tangible expression of their willingness to join the nation, and show that they now accept the responsibilities that arise from membership in the nation as an ethical community.

According to Miller, this double commitment is best enabled if there are policies in place that symbolize a "moral contract" by which immigrants join the national political community, with its rights and responsibilities (Miller 2006). This moral contract should be visible in the welfare state. It might be appropriate, for example, to withhold access to certain social rights until immigrants have made a good-faith commitment to fit into the national political culture. In any event, Miller maintains, we should avoid at all costs a situation in which immigrants are given rights and recognition without asking or expecting for a commitment to the nation in return. Miller worries that multiculturalism policies are sometimes seen as taking this perverse form of granting rights to the recognition of difference without asking for a reciprocal commitment to the nation. This, Miller worries, is seen as violating the norms implicit in the ethical community of nationhood, and hence as exacerbating native-born resistance to immigration.

On Miller's view, then, national identity can play an important role in overcoming the corrosive effects of diversity on the welfare state- indeed, he thinks it is an essential factor for this to happen-but it can only play this role if it is tied to policies that encourage and make visible a shared commitment to the moral contract of nationhood.

Here again, this liberal nationalist idea is not without its critics. Some theorists argue that attempting to incorporate newcomers and ethnic minorities into national cultures is an 
anachronistic idea, suited to a $19^{\text {th }}$-century world of Westphalian nation-states, but out of touch with the realities of contemporary globalization and mobility. Moreover, it may be impossible to remove the ethnic or racial components of older national identities: not all national identities can be reconstructed in ways that make them truly open and inclusive to newcomers and minorities. On this view, we need to sever the connection between solidarity and nationhood, and find a "post-national" basis for the welfare state that connects social rights solely to the fact of residence or universal personhood, not membership/integration in the nation (e.g., Soysal 1996). According to this view, the proper response to the corrosive effects of diversity on national solidarity is not to nationalize the diversity, but rather to denationalize solidarity.

While this issue has been widely discussed in the literature, it has not been adequately tested empirically. Several studies have examined the link between national identity and attitudes towards immigrants, with mixed results, partly depending on how national identity is defined and measured. National identities carry potentially contradictory charges. To the extent that their content is ethnic or cultural, they may clash with immigration and immigrants. Sniderman's and Hagendorn's (2007, pp. 119-21) “mere mention” experiment is telling in this respect. While empirical studies of civic nationalism, or "constructive patriotism," are gaining ground (see for instance, deFigueirido and Elkins 2003), these studies rarely explore how this link between national identity and anti-immigrant attitudes connects to support for the welfare state. The extent to which national identities can be made inclusive of immigrants, and the extent to which such national identities can then provide a source of solidarity, remain open questions.

\section{The Canadian Case}

Canada provides a social laboratory for testing ideas about the potential of national identity to mitigate the effects of economic interest and ethnic diversity. While the Canadian social policy 
regime is less extensive than that in many northern European countries, it represents a more ambitious social role for the state than that in the US, with universal public health care and a more redistributive structure of income security programs. Canada also manifests the potential sources of resistance to redistribution at the centre of this study. The gap between rich and poor lies broadly in the middle of the range for OECD countries, and the direction of change has been similar to that elsewhere. Since the 1990s, Canada's gini coefficient moved from just below to just above the average for the OECD as a whole (OECD 2008). In addition, Canada is one of the most multicultural countries in the world (Fearon 2003). Over the last half century, the ethnic composition of the population has been transformed by changing patterns of immigration, and 20 percent of the people now living in Canada were born outside the country. Moreover, in contrast to some host countries whose immigrants come predominantly from one part of the world, creating a relatively homogeneous "Other," newcomers to Canada come from around the globe, contributing to a "diverse diversity" of ethnicities, races, and religions.

National identity is a richly complex phenomenon in Canada. Indeed, Canada is for many a multination state, in which the Québécois see themselves and are increasingly seen by others as a distinct nation, and the Aboriginal peoples define themselves as First Nations. It is an interesting question how the distinctive national identities of the Québécois and Aboriginals affect their views of the appropriate scope of redistribution. But this question requires either a vast set of parallel statistical analyses or complex and highly collinear multi-way interactions; both strategies are beyond the scope of a single journal article. Accordingly, we focus on Canadians who are not French-speaking Quebecers, not visible minorities, not First Nations, and not immigrants. Technically, our sample therefore consists of white native-born respondents who are not Quebec francophones. Although these respondents are just one sub-section of Canadians, 
they clearly constitute a group that Miller's hypothesis identifies as highly salient for issues of national identity and solidarity.

\section{OUR ANALYSIS AND RESUlts}

The data for this study come from the second wave the Equality, Security and Community survey, with fieldwork conducted in 2002 and 2003. The sample combines a national probability component with a metropolitan Montreal-Toronto-Vancouver oversample drawn from census tracts with relatively heavy concentrations of visible minorities. ${ }^{\text {iii }}$

Our analyses involve indicators of support for the welfare state, of national identity, of trust in persons and in government, and of economic position: ${ }^{\text {iv }}$

- For support for the welfare state, we deploy separate indicators for public pensions, equality of access to health care, and redistribution toward the poor and economically vulnerable. ${ }^{\mathrm{v}}$ Miller's account generates subtly different expectations for each domain. His focus on interpersonal trust points to moral hazard as the vital consideration, which makes redistributive policies especially vulnerable. Among social insurance domains, health care may also be a candidate, to the extent that health services are vulnerable to willful overclaiming.

- Our indicator of identification with Canada combines four measures: a rating of how much the respondent feels he or she belongs to the Canadian community, how proud the respondent is to be Canadian, how important it is to be Canadian, and the respondents' raw feeling toward the country on a $0-100$ scale. This indicator is utterly neutral on the content of identification with Canada. It embodies no normative claim about what it means to identify with the place, neither an ethnic definition nor a liberal or multicultural one. It combines what Citrin et al. (2001) felicitously describe as "identification as" and "identification with." 
This is not to say that identification so measured must ex hypothesi lack normative punch. If it does produce the empirical effects hypothesized by Miller, then we might infer that the majority identity has become a liberal (or perhaps multicultural) one. Critically, we could not stand accused of producing the relationship as a measurement artifact. ${ }^{\mathrm{vi}}$

- Our indicators of trust correspond exactly to those described in Soroka, Helliwell, and Johnston (2007). Interpersonal trust is indicated by a four-item battery of perceived likelihood that a lost wallet or purse would be returned. Variance in this measure roughly corresponds to that in the more ubiquitous generalized trust item, but the wallet indicator is more robust. The trust in government measure combines response to a commonly used question about trusting the federal government "to do what is right" with warmth of feeling toward that government.

- Economic position attempts to capture respondents' objective stakes in a capacious welfare state. It includes household income, whether or not the respondent fears losing his/her job or business in the next twelve months, and the respondent's subjective evaluation of their household economic position over the preceding twelve-months. Also included is age, to capture likely dependence on pensions and near-term need for health care. Gender appears, as female labour force participation is a major driver of actual welfare-state spending (even as certain forms of spending enable such participation). Whether or not any member of the family belongs to a trade or labour union also appears. Objectively, union families may be less at risk than others but the union movement nonetheless represents a major ongoing source of pro-welfare state advocacy. The indicator includes two categories related to work status: whether or not the respondent has been unemployed or on short time in the preceding twelve months; and whether they fall outside the labour force (these are mostly homemakers, 
students, and retired persons). Unemployment/underemployment speaks for itself. Nonparticipation appears to sharpen the possible effects from age and gender. These factors correspond to the "workhorse model" in the welfare-state literature (See, e.g., Corneo and Gruner 2002; Cusack et al. 2006; Fong 2001; Iversen and Soskice 2001; Linos and West 2003). Rather than encumber analyses with the full set of these variables, we instead derive summary indicators. We begin by regressing the measure of support for each welfare-state scale on the "workhorse" variables, and then capture the net effect of the economic variables taken together by saving the predicted values. ${ }^{\text {vii }}$ By construction, the slope of the bivariate relationship between the summary variable and its welfare-state scale of interest is -1 . This then facilitates a very parsimonious representation of how impact from the economic basis of welfare-state support is mediated or conditioned by some third variable, say, identity or trust. $^{\text {viii }}$

Attitudes to immigrants and immigration are captured by a two-item index. One item goes to the heart of Miller's anxieties about whether immigrants will accept the obligations that go with the privileges of membership, by asking whether or not "recent immigrants" want to "fit in." The mention of "recent" may carry an ethnic or racial subtext, since recent immigrants to Canada are predominantly non-European. Response to this item is closely related to a question that asks whether the country is accepting too many or too few immigrants. On one hand, this may seem to shade the analysis away from Miller's central concern and to conflate two morally distinct zones. But the two-item indicator carries more charge than the singleitem one.

All measures are constrained to the 0-1 interval for ease of interpretation. Where applicable, scale reliability coefficients, alongside basic descriptives, are included in the Appendix. ${ }^{\text {ix }}$ 
All estimations are confined to a subsample that makes for straightforward estimation: native-born white (non-visible minority, and non-First Nations) respondents residing outside Quebec. As noted above, this focuses on the group most central to Miller's account, the persons most susceptible to arguments from an "ethnic" definition of the nationality and for whom the presence of immigrants and racial minorities might be problematic.

\section{[TABLE 1 ABOUT HERE]}

\section{Does identity produce solidarity across differences in economic position?}

We begin with Miller's first argument, that national identity helps produce solidarity among citizens, such that even economically fortunate persons support the welfare state in general and its specifically redistributive parts in particular. ${ }^{\mathrm{X}}$ Table 1 confirms that this is so, in a manner of speaking, for our sample. Effects are more impressive for opinion on health and pension policy than on redistribution, however, as indicated by model (1) for each domain. The claim is based on a combination of "main" and "interaction" terms. The main-effect coefficient for economic position indicates impact where values on the identity variable are zero, that is, for respondents who absolutely abhor their home and native land. The main effect for identity captures respondents who score zero on the economic position variable, persons who are maximally vulnerable. The interaction term captures how the effect of each variable is conditional on values of the other. With all variables set to the $0-1$ interval, the coefficient indicates how much the slope of effect from one variable grows or shrinks as the other variable grows from 0 to 1 .

Among persons who do not identify with Canada, the impact from economic position is strikingly negative. The biggest such effect is for opinion on health—almost twice that on redistribution and three times that for pensions. For persons as the bottom of the economic heap identity makes essentially no difference for welfare state opinion. Except, that is, for redistribu- 
tion, where the effect is arguably perverse. We should not make much of this, as we shall show in a moment. For each of redistribution and health, the interaction between economics and identity is massively positive. For redistribution, shifting to complete identification with Canada eliminates about two-thirds of the initially negative economic relationship. For health, the impact is almost total: 90 percent of the initial slope is erased.

\section{[FIGURE 1 ABOUT HERE]}

The difficulty is that these seemingly massive effects capture contrasts between implausible extremes. Figure 1 brings us to earth by plotting variance across interquartile ranges. Thus, "low" and "high" values for economic position and for identity correspond to the $25^{\text {th }}$ and $75^{\text {th }}$ percentiles. ${ }^{\text {xi }}$ For those with "low" Canadian identity, moving across the range of economic position shown here reduces support for redistribution from 0.62 to 0.54 on the $0-1$ scale. For those with "high" identity, the impact of economic position is markedly smaller. Relationships in the other welfare subdomains are larger. For health care, Canadian identity is a powerful moderator. At the $75^{\text {th }}$ percentile of identity, economic position has virtually no effect. At the $25^{\text {th }}$ percentile, conversely, economic position has roughly the same effect as on redistribution. Most impressive, however, is that regardless of economic position, identity has a powerful direct effect on support for health care. ${ }^{\text {xii }}$ For pensions, there is effectively no interaction of economic position with identity. There is a small direct effect of identity, however, illustrated by the gap between the lines in the bottom panel of Figure 1. For pensions the impressive effect is from economic position itself: moving from the $25^{\text {th }}$ to the $75^{\text {th }}$ percentile cuts support for public pensions by 0.13 . This across-the-board economic impact is over twice as large as in the average impact on health or redistribution opinion. 


\section{Are identity effects mediated by trust? If so, what kind of trust?}

Miller conjectures that the effect of national identity is to elevate levels of trust. On his account, interpersonal trust is the key; it is induced by patriotism, and it is critical in turn to resource pooling and risk sharing. Miller also concedes a place for trust in government, especially as it is a backstop for trust among persons. The first part of the syllogism is captured in Table 2: identity is positively associated with both forms of trust, and is so with the economic position "workhorse" controlled. ${ }^{\text {xiii }}$ But identity is far more important for trust in government than for interpersonal trust-the impact of an identity shift is twice as great on the former as on the latter. $^{\text {xiv }}$

\section{[TABLE 2 ABOUT HERE]}

The second part of the syllogism is captured by estimation (2) in each domain of Table 1. Again, the critical type of trust is not interpersonal but governmental. With both forms of trust in the setup, the "main effect" coefficient for "economic position" now indicates impact for an utter misanthrope, someone who despises Canada and reposes no trust in either persons or institutions. The negative slope is, as in the earlier interaction, very steep; indeed, for pensions it strengthens relative to model (1). Identity main effects typically weaken, but they were never strong to begin with. Interactions between identity and economic position also weaken and - for health and pensions - slip below the horizon of statistical significance; this reflects collinearity and the inflation of standard errors, as well as by the fact that some of the impact of identity is transmitted through trust, just as Miller conjectures. The coefficients themselves suggest that, even with trust terms in the setup, feeling maximally good about Canada cuts the workhorse relationship in half for both redistribution and health. Similarly, with the identity term in the equation, moving to a position of complete trust in government also cuts the workhorse 
relationship in half. Moving from maximum misanthropy to maximum philanthropy eliminates impact from the workhorse; identity and trust overcome narrow self-interest.

\section{Do anti-immigrant attitudes undermine support for the welfare state? And does national}

\section{identity matter to the relationship?}

Anti-immigrant attitudes do undermine support for redistribution among native-born whites in English Canada, according to models (3) in Table 1. Going from one extreme to the other in support for immigrants reduces support for redistribution by about 0.13 points on the $0-1$ scale. The effect is one half as large for health (0.07), and is essentially non-existent for pensions. We see, then, an echo of Miller's concern about moral hazard: anti-immigrant sentiment is most clearly linked to the welfare-state domain most susceptible to abuse and defection—at least most susceptible to rhetoric about abuse. Opposition to immigration does not interact with any other factor; it is just another element in the mix. ${ }^{x v}$

Canadian identity counteracts this toxic relationship in two distinct ways. First, identification with Canada reduces anti-immigrant sentiment. Second, national identity compensates for the anti-immigrant sentiment that persists, adding an additional form of protection for the social role of the state.

The first of these relationships is captured in the rightmost column of Table 2 .

Identification with Canada does induce a welcoming posture toward immigrants, and again this role is especially critical among the economically well off. As in Table 1, the economic position "main effect" captures the relationship between economic position and immigration attitudes for someone who utterly abhors Canada. The corresponding Canadian identity "main effect" describes persons at the bottom rung on the economic ladder. The interaction term captures how economic effects shift between identity extremes. ${ }^{\text {xvi }}$ Taken at face value, the coefficient on 
economic position (2.8) says that, for someone with no identification with Canada, a unit upward shift in economic position induces nearly a three-unit gain in anti-immigrant attitudes. The point should be clear: if you are sour on Canada, getting richer makes you more xenophobic, not less. If you undergo a massive change of heart and become wholly devoted to the country, the relationship turns on its head: the powerful positive relationship becomes a modest negative one: getting richer now makes you slightly less anti-immigrant. This is captured visually in Figure 2, which plots the relationship between economic position and anti-immigrant attitudes for the $25^{\text {th }}$ and $75^{\text {th }}$ percentiles on each indicator. At the $25^{\text {th }}$ percentile on identity, the slope on economic position is robustly positive; at the 75 th percentile of identity, the slope on economic position is slightly negative. The figure also makes it easy to see that the interaction runs both ways: among the economically vulnerable, identity matters less than among the better off-the identity gap is almost twice as great among the comfortable as among the afflicted. Evidently, Canadian identity for our respondents includes "new" Canadians, in the sense that close identification with

the country promotes, rather than inhibits, openness to newcomers. ${ }^{\text {xvii }}$ And xenophobia is not the peculiar property of the poor.

\section{[FIGURE 2 ABOUT HERE]}

At the same time as it reduces anti-immigrant sentiment, identification with Canada compensates for it, at least for opinion on health policy. This is seen by cycling back to models (3) in Table 1 and comparing them with models (1). Adding immigration opinion to the estimation leaves estimated values for the identity terms and their interactions much as before. For redistribution, the domain most affected by anti-immigrant sentiment, the main and interaction effects for identity are reduced only slightly relative to the model (1) baseline. For health policy, the identity terms are as strong as before and, also as before, stronger than for the 
other welfare-state domains. Identity remains irrelevant to pension opinion, but so is antiimmigrant sentiment. For redistribution, then, identification with Canada exerts some amount of counter-pressure to xenophobia. For health, the counter-pressure looks very strong.

But the compensation suggested by Table 1 is largely hypothetical. If identification with Canada were to shift across the range implied by the coefficients—-for either redistribution or health care-negative feelings about immigrants would be more than compensated for. But the identity indicator varies little, as the distribution is crowded toward the top end. Immigration opinion, conversely, is quite balanced: about as many respondents have negative views of immigrants and immigration as hold positive ones. A more realistic picture, with contrasts across interquartile ranges, can be found in Figure 3. Differences among policy domains appear with special clarity. For redistribution, when values are actually—as opposed to hypothetically_ distributed, immigration trumps identity. For health and pension policy, the two forces roughly balance each other, as ambivalent persons roughly split the difference between the anti-Canada anti-immigrant and pro-Canada pro-immigrant extremes. But the struggle is most titanic for health policy, where the gap between extremes (especially among the well-off) is over 0.10 points. For redistribution, as we already know, the big story is not about identity or xenophobia, but about economic position. ${ }^{\text {xviii }}$

\section{[FIGURE 3 ABOUT HERE]}

\section{CONCLUSIONS AND REFLECTIONS}

Clearly, national identity has considerable significance for the welfare state in Canada. At the most general level, our results provide support for the intuitions and arguments advanced by liberal nationalists. But identity plays a narrower role than existing theories suggest, and the mechanisms through which it works are different, at least in Canada. 
Consider first the role of national identity in building support for the welfare state among affluent members of society. Recall that Miller sees national identity as playing a two-fold role. One role is direct, in creating sympathy for co-nationals. The other role is indirect, by increasing trust, especially interpersonal trust. Miller sees national identity as especially important to programs that redistribute resources vertically to poor, as opposed to universal services that protect the population as a whole.

We find only partial support for this interpretation. National identity does increase general support for the welfare state among affluent respondents. However, the effect is most marked for health care, a universal program in Canada, and is barely noticeable both for pensions, another universal program, and for redistribution to the worst off. As we shall see, this variation across subdomains is important. Second, while national identity has an impact on both interpersonal trust and trust in government, most important in strengthening pro-welfare state sentiments is the link with trust in government. In short, national identity supports the welfare state not primarily by reinforcing the interpersonal trust needed to sustain the distinctly redistributive aspects of the welfare state, but more by reinforcing the governmental trust that legitimates state intervention in people's lives.

Consider next national identity in the context of immigration and ethnic diversity. Recall that Miller and other liberal nationalists do not argue that people with a strong sense of national identity are more supportive of redistribution to "foreigners" or "newcomers." Rather, they argue that native-born citizens need to believe that newcomers are joining the nation and accepting the responsibilities that membership brings.

At one level, our findings are consistent with this broad pattern. As Miller would predict, respondents who believe that immigrants do not want to fit in show markedly lower support for 
the redistributive dimensions of the welfare state. So viewing immigrants as worthy new members of the nation sustains support for redistribution. But our findings show something else that Miller would not predict: namely, that national identity itself promotes such pro-immigrant sentiment. Those with the strongest sense of national identity embrace immigration and immigrants more warmly than their less nationalist neighbours. Miller's theory predicts that members of the host society with a strong national identity will care whether immigrants want to join the ethical community; but our findings show that those in our sample with a strong national identity are more likely to give immigrants the benefit of the doubt, and hence are more likely to interpret immigrants' behaviour as evidence of a desire to integrate. Moreover, identity exerts its greatest effect among the affluent; rich folks who dislike their country also dislike its newcomers. Fortunately for Canada, such people are not numerous.

If national identity and the welfare state are mutually supportive in Canada (even if in ways not fully anticipated by liberal nationalists), the obvious question is whether this experience is distinctive, or whether similar patterns should emerge elsewhere. As we noted earlier, the evidence from other countries argues for caution in generalizing results from Canada. Crossnational studies do not suggest any systematic tendency for strength of national identity to correlate with either stronger support for the welfare state or warmer attitudes towards immigrants. Indeed, some studies suggest the opposite tendency. ${ }^{\text {xix }}$ These contrasting findings may reflect differences in measurement, for both national identity and support for the welfare state. Some studies measure national identity by asking about people's sense of "belonging" to the nation; others ask about how strongly people "identify with" the nation; yet others ask how much people feel "pride" in their nation, or in particular aspects of their nation (such as its history, culture, laws, or institutions). Other studies use even more indirect measures of national identity (such as 
whether one prefers policies to be made at the national level or the EU level). These indicators tap somewhat different sentiments, with potentially different relationships to solidarity. ${ }^{\mathrm{xx}}$ The same is true for welfare state indicators. Some studies rely on general attitudes about narrowing the gap between rich and poor (Shayo 2009). Our findings underscore the importance of examining support for specific programs and subdomains of the welfare state.

Divergence among findings cannot be the product solely of measurement, however. Even with standardized measures, the direction and strength of national-identity effects are likely to vary cross-nationally. Relationships are likely to be highly contingent, reflecting distinctive features of the history and culture of each country. Consider the role of national identity in mitigating the impact of the economic self-interest of affluent voters. Here, the evidence for uneven impact across subdomains of the Canadian welfare state is highly suggestive. The link is clearest for health care, which is not surprising given that for many English-speaking Canadians, "medicare" has become part of the very definition of the country. The nation-wide reach of the system has been celebrated as part of the social glue that holds together a society otherwise divided by language and region; and its universal coverage is widely seen as one of the defining features distinguishing Canada from its powerful neighbour to the south. It has therefore been relatively immune to explicit attempts at privatization and downsizing. But national identity has not spread a similarly protective umbrella over other parts of the welfare state, including both other universal programs such as pensions and targeted programs designed to redistribute to the poor.

If this logic is correct, one might expect considerable variation in the relationship between national identity and the welfare state. The welfare state, or specific programs within it, has played a different role in the nation-building projects and national narratives of different 
countries, and may be more closely linked to national identities in some times and places than others. Put another way, national identity may not have any general tendency to strengthen support for redistribution, but it may do so for those aspects of the welfare state seen as having played a particularly important role in building the nation, or in enabling it to overcome particular challenges or crises. This undoubtedly varies from country to country. In some countries, such as the United States, national identity may have very little to do with redistribution, or may have a negative impact. In other countries such as Sweden, the universalistic conception of the welfare state may now be seen as part of what it is to be Swedish. Other countries may nestle with Canada in the middle ground, where some subdomains have an iconic status but others do not. The possible role of the National Health Service in the United Kingdom comes to mind. In short, it is not the intensity of identity that matters but its specific relationship to the dominant nation-building narratives. ${ }^{\mathrm{xxi}}$

What about the role of national identity in protecting the welfare state from cultural suspicion of newcomers? Here again the relationship is likely to be highly contingent. For those in our sample (native-born white respondents who are not Quebec francophones), the very selfconception of the country has come to embrace the idea of a multicultural society which successive waves of immigrants have helped build. Levels of national pride are high, and diversity and multiculturalism have come to be seen as distinctly Canadian virtues. In short, for this group, multiculturalism is now a part of Canadian nationalism. ${ }^{\text {xii }}$ There are of course many mythical elements in the self-concept, but this highly multicultural form of nationalism (or, if you prefer, a highly national form of multiculturalism) helps mitigate the toxic effects that antiimmigrant sentiment might otherwise have for the welfare state. There are undoubtedly other countries which exhibit this sort of national pride in multiculturalism, and hence where 
strengthened national identity can reduce xenophobia, but it seems unlikely to be a general tendency across all countries, independent of the more specific content of their national imaginaries and narratives.

In short, the findings in this paper suggest that the liberal nationalist goal of building national identities that are simultaneously multicultural and solidaristic is not an impossibility, and that such national identities can help sustain the welfare state in multiethnic states. Our findings also suggest that this possibility is rooted in more complex and contingent processes than existing theories of liberal nationalism allow. 


\section{Notes}

${ }^{\text {i }}$ For instance: "Much state activity involves the furthering of goals which cannot be achieved without the voluntary co-operation of citizens. For this activity to be successful, the citizens must trust the state, and they must trust one another to comply with what the state demands of them" (Miller 1995: 90-91). Miller implies that national identity promotes both forms of trust (in state and in co-citizens), but focuses on the latter.

ii Though note that the individual-level relationship was less evident in industrializing countries.

${ }^{\text {iii }}$ A detailed description of the logic of the ESC can be found in Soroka, Helliwell, and Johnston (2007) and Soroka, Johnston, and Banting (2007a). The ESC is a RDD telephone survey, with a first wave conducted in 2001 and a second conducted in 2002-2. Across the national probability samples and the metropolitan oversamples in Wave 1, the response rate (AAPOR RR3) was $51 \%$, with virtually no difference between main and oversamples. The response rate for new respondents in Wave 2 was similar, while the reinterview rate for panel respondents in Wave 2 was $45 \%$ ( $52 \%$ for the national and $21 \%$ for the oversample).

${ }^{\text {iv }}$ Indexes and related survey questions are described in detail in an appendix available from the authors on request.

${ }^{v}$ Details on each can be found in the Appendix as well as in Soroka, Johnston, and Banting (2007a).

${ }^{v i}$ The distribution of identification with Canada maps sensibly onto the country's ethnocultural structure: Quebec francophones identify with Canada less than visible minority persons and immigrants of European ancestry do, and these latter two groups identify with the country less than do native-born persons of European ancestry living outside of Quebec. European/nonEuropean and immigrant/native contrasts are almost entirely the product of time-of-immigration: 
the longer an immigrant has been in the country, the higher the rate of identification; and nativeborn members of visible minorities are essentially indistinguishable from the native-born "majority" (Soroka, Johnston and Banting 2007b). For reasons outlined below, analysis is confined to the native-born non-Quebec Euro-Canadians.

${ }^{\text {vii }}$ Full results of first-stage estimations appear in Appendix Table A1.

viii The model makes several rather large assumptions, including the fact that each economic variable is assumed to be equally mediated by the third variable, and that the relative magnitude of the effect of each economic variable does not change from the first-stage to the second-stage model, even as all the interactions are introduced. Neither of these assumptions will be perfectly true, of course. That said, the findings below are supported by models in which all economic variables are interacted individually with the third variable. Even as the magnitude of individual economic variables is marginally different, the main story is exactly the same. And the loss of detail is, we believe, far outweighed by the advantage of being able to explore the effect of the mediating variables in a parsimonious way.

${ }^{\text {ix }}$ In the case of opinion on health care, the variable is a simple dichotomy. To facilitate comparison with the other welfare-state domains, all estimations for health care are in OLS. In every case, compared OLS results with those by probit and found essentially no difference.

${ }^{\mathrm{x}}$ It is worth noting that identification with Canada is at best only weakly associated with economic position. See Table 2 .

${ }^{x i}$ The $25^{\text {th }}$ and $75^{\text {th }}$ percentiles of identity are not that far apart, a gap of 0.21 . Indeed, not even the $10^{\text {th }}$ and $90^{\text {th }}$ percentiles are all that distant, a gap of just over 0.3 . Recall that these respondents are all native-born Anglophones of European ancestry residing outside Quebec, a group for whom Canadian identity is especially skewed. The data in Figure 1, and in subsequent 
figures, are estimates, and as such have associated confidence intervals. For the sake of clarity, we do not show these here. Suffice it to say that our discussion in the text reflects the statistical significance of the various relationships, as indicated by the tables.

xii Though note that values on the $y$-axis are much higher here than for redistribution, reflecting the fact that support for healthcare is higher across the board.

xiii For simplicity, the "workhorse" here comprises predicted values from the redistribution estimation in Appendix Table A1. If we free parameters for workhorse variables in trust estimations, we get slightly closer fits to the data.

${ }^{\text {xiv }}$ One possible concern here is that national identity and trust in government are in fact capturing the same underlying disposition. The two measures are, in the sample used here, correlated at $.34(\mathrm{p}<.01)$. While the relationship between the two is strong, however, we see the two as theoretically separate phenomena. This is also supported by the data. Adding trust in government to the four items in the national identity scale reduces the Cronbach's alpha. (See Appendix for scale reliability coefficients.) And the R-squared on the model in Table 2 is after all just .11. ${ }^{\mathrm{xv}}$ Strictly speaking the setup in Table 1 suppresses interactions involving immigration. But as preliminary analyses indicated that none existed, we opted for presentational simplicity. ${ }^{x v i}$ Equally, it describes how the identity slope shifts with movement between economic extremes. Conceptually, however, it is easier to think of how identity conditions economics than the reverse.

${ }^{\text {xvii }}$ We should not exaggerate the ultimate result of this relative openness, however, as even those most strongly identified with Canada are evenly divided over immigrants and immigration (Note the scale on the y-axis in Figure 2). 
${ }^{\text {xviii }}$ We must acknowledge that all of these claims rest on potentially weak measures and relatively strong assumptions. On one hand, both orientations are measured with some error, with possibly adverse effects on their estimated coefficients. On the other hand, the impact we find for immigration attitudes on welfare-state opinion, especially on redistributive policy, may actually reflect causation in the other direction. We have accordingly attempted to address these concerns with alternative estimation strategies. To address measurement error, we re-estimated all models in Table 1with errors-in-variables (EIV) regressions. Not surprisingly, coefficients shifted considerably in completely predictable ways: correction for error strengthened the estimated impact of poorly-measured variables and did so at the expense of well-measured ones. Critically for our purposes, the basic structure remained intact. To address endogeneity we ventured onto 2SLS turf. As is typical of such forays, findings were inconclusive; that is, there was no clear evidence of unidirectional effects in either direction. Accordingly, we are not committed to a strong position on causal direction between identity and solidarity. The critical message, in our view, is that the relationship is positive, not negative and not null. Results are available from the authors upon request.

${ }^{\text {xix }}$ Shayo 2009 reports a negative relationship between strength of national identity and support for redistribution across the Western democracies; Sides and Citrin 2007 and Mayda 2006 report a negative relationship between strength of national identity and support for immigrants across Europe.

${ }^{\mathrm{xx}}$ There is in fact a rapidly-growing literature which attempts to distinguish (and measure) different forms or bases of national identity, such as ethnic versus civic nationalism; nationalism versus patriotism; patriotism versus chauvinism; blind patriotism versus constructive patriotism, 
and so on. These studies show, predictably, that the more ethnic/chauvinistic/blind forms of nationalism are more xenophobic.

${ }^{x x i}$ For a similar interpretation, see Béland and Lecours 2008, especially pp. 208-210.

xxii On the emergence of this distinctly "multicultural nationalism" in Canada, see Uberoi 2008 and Kernerman 2005. 


\section{Appendix}

This appendix lists the details for each variable used in preceding analyses. Where necessary, question wording is included. Appendix Table A1 includes the first-stage estimations for "Economic Position," as discussed in the text.

Variables in the "workhorse" models of Economic Position. Gender is a dummy variable, =1 if respondent is female; Age is a set of dummy variables for 30 to 49, 50 to 65, 66 and over; residual category is $<30 \mathrm{yrs}$; Education is a dummy variable equal to one if the respondent has more than a high school education; Income is missing for a good number of respondents, so we fill in missing data through interpolation (details are available upon request); Fear of job loss is based on the following question, "How likely is it that you will lose your job in the next 12 months? Would you say it is very likely, somewhat likely, not very likely, or not at all likely?"; household economic situation is based on the following question: "Thinking about the past twelve months, has your household's economic situation improved, stayed about the same, or worsened? “

Identification with Canada. Based on the following questions: (1) "Please tell me how much you feel that you belong to the following places. Using a scale from 1 to 10 where 1 means you feel like you do not belong at all and 10 means you feel that you belong completely, what number best describes how you feel about Canada?," (2) "How proud are you to be Canadian: very proud, quite proud, not very proud, or not at all proud?," (3) "Is being Canadian very important to you, somewhat important, not very important, or not important at all?," and (4) Now I'll ask you to rate various places and institutions on a scale that runs from 0 to 100 . Ratings between 0 and 50 mean that you rate them unfavourably. Ratings between 50 and 100 mean that you rate them favourably. You may use any number from 0 to 100 . What about Canada?" The variables are rescaled from 0 to 1 and given equal weighting. The in-sample mean is .855; the standard 
deviation is .140. The Cronbach's alpha for the 4-item index is .690, and dropping any single item reduces the scale reliability.

Interpersonal Trust. Based on the following question: "Say you lost a wallet or purse with $\$ 100$ in it. How likely is it that the wallet or purse will be returned with the money in it if it was found by a [neighbour]? Would you say it is very likely, likely, or not at all likely?" The question is repeated four times, for a neighbour, a police officer, a clerk at the local grocery store, and a stranger; the variable is $=1$ for very likely, $=.5$ for likely, and $=0$ for not at all likely. The insample mean is .689; the standard deviation is .208. The Cronbach's alpha for the 4-item index is .647 , and dropping any single item reduces the scale reliability.

Trust in Government. Based on the following questions: (1) "How much do you trust the government in Ottawa [or province] to do what is right?," (2) 100-point feeling thermometer for the federal government. The variables are rescaled from 0 to 1 and given equal weighting. The insample mean is .425 ; the standard deviation is .216. The Cronbach's alpha for the 2-item index is .758

Redistribution. Based on the following questions: (1) "Many unemployed persons could find work if they really wanted to." [Agree or disagree.] "How many do you think could find work: about one quarter, about one half, about three quarters, or almost all of them could find work?," (2) "In Canada today, do you think it is too easy or too hard to get unemployment insurance?," (3) "Is the unemployment benefit, that is the amount of money people receive when they are unemployed, too high or too low?," (4) "Which is closer to your own view: One, refusing welfare to single parents, is unfair to their children. Two, giving welfare to single parents rewards irresponsible behaviour," (5) "Again, which is closer to your own view: One, people on welfare are usually there for only a short time and are unlikely to be on it again, two, once people get on wel- 
fare they usually stay on it," (6) "Now I'm going to read some statements and ask if you AGREE or DISAGREE. The government must do more to reduce the income gap between rich and poor Canadians," (7) "Now I'm going to read pairs of statements and ask, for each pair, which is closer to your own view: One, the government should see to it that everyone has a decent standard of living, OR, two, the government should leave it to people to get ahead on their own." The variables are rescaled from 0 to 1 and given equal weighting. The in-sample mean is .583; the standard deviation is .210. The Cronbach's alpha for the 7-item index is .523, and dropping any single item reduces the scale reliability.

Support for Health Care. Based on the following question: "Which is closer to your own view: One, everyone should have equal access to health care, even if that means waiting for treatment, OR [TWO, if you can afford it you should be able to buy faster access to health care.] OR [Two, if you are willing to pay for it you should be able to buy faster access to health care.]" The insample mean is .802; the standard deviation is .399 .

Support for Pensions. Based on the following questions: (1) "When it comes to saving for retirement would CANADA/ CANADIANS/YOU be better off if the Canada Pension Plan was shut down and individual Canadians/Canadian/you were able to invest their money for themselves/yourself?," and (2) "Government pensions are the only way to ensure that all Canadians have at least some income in their old age." The variables are rescaled from 0 to 1 and given equal weighting. The in-sample mean is .772; the standard deviation is .320. The Cronbach's alpha for the 2-item index is .287.

Attitudes towards Immigration. Based on the following questions: (1) "Too many recent immigrants just don't want to fit into Canadian society. Do you agree or disagree?," and (2) "Do you think Canada should admit more immigrants or fewer immigrants than at present?." The va- 
riables are rescaled from 0 to 1 and given equal weighting. The in-sample mean is .589; the standard deviation is .397. The Cronbach's alpha for the 2-item index is .506. 


\section{REFERENCES}

Abizadeh, Arash 2002. Does Liberal Democracy Presuppose a Cultural Nation? Four Arguments. American Political Science Review 96: 495-509.

Alesina, Alberto, Reza Baqir, and William Easterly. 2001. Public goods and ethnic divisions. NBER Working Paper no. 6009. Cambridge, Mass: NBER.

Alesina, Alberto, and Edward Glaeser. 2004. Fighting Poverty in the US and Europe: A World of Difference. Oxford: Oxford University Press.

Banting, Keith, and Will Kymlicka, eds.. 2006. Do Multiculturalism Policies Erode the Welfare State? Oxford: Oxford University Press.

Barry, Brian. 1991. Democracy and Power: Essays in Political Theory. Oxford: Oxford University Press.

Béland, Daniel and André Lecours 2008. Nationalism and Social Policy: The Politics of Territorial Solidarity. Oxford: Oxford University Press.

Canovan, Margaret. 1994. Nationhood and Political Theory. Cheltenham: Edward Elgar.

Citrin, Jack, and Donald Philip Green. 1990. The Self-Interest Motive in American Public Opinion, in Samuel Long, ed. Research in Micropolitics, Volume 3. Greenwich, Conn: JAI Press.

Citrin, Jack, Cara Wong, and Brian Duff. 2001. The Meaning of American National Identity, in Richard D. Ashmore, Lee Jussin, and David Wilder, eds. Social Identity, Intergroup Conflict, and Conflict Reduction. New York: Oxford University Press, pp. 71-100.

Corneo, Giacomo, and Hans Peter Gruner. 2002. Individual preferences for political redistribution. Journal of Public Economics 83: 83-107. 
Crepaz, Markus. 2008. Trust Beyond Borders: immigration, the welfare state and identity in modern societies. Ann Arbor: University of Michigan Press.

Cusack, Thomas, Torben Iversen, and Philipp Rehm. 2006. Risks at work: The demand and supply sides of government redistribution. Oxford Review of Economic Policy 22: 365-389.

De Figureido, Jr., Rui J.P., and Zachary Elkins. 2003. Are Patriots Bigots? An Inquiry into the Vices of In-Group Pride. American Journal of Political Science 47: 171-88.

Easterly, William. 2001. The Elusive Quest for Economic Development: Economists' Adventures and Misadventures in the Tropics. Cambridge, Mass: MIT Press.

Esping-Andersen, Gosta. 1990. The Three Worlds of Welfare Capitalism. Princeton, NJ: Princeton University Press.

Fearon, James. 2003. Ethnic and Cultural Diversity by Country. Journal of Economic Growth 8: 195-222.

Fong, Christina. 2001. Social preferences, self-interest, and the demand for redistribution. Journal of Public Economics 82: 225-246.

Gilens, Martin. 1999. Why Americans Hate Welfare: Race, Media and the Politics of Antipoverty Policy. Chicago: University of Chicago Press.

Goodhart, David. 2004. Too Diverse? Prospect., February, pp. 30-37

Hicks, Alexander. 1999. Social Democracy and Welfare Capitalism: A Century of Income Security Policies. Ithaca: Cornell University Press.

Huber, Evelyne, and John Stevens. 2001. Development and Crisis of the Welfare State: Parties and Policies in Global Markets. Chicago: University of Chicago Press.

Iversen, Torben, and David Soskice. 2001. An asset theory of social policy preferences. American Political Science Review 95: 875-893. 
James, Estelle. 1987. The public/private division of responsibility for education in international comparison. Economics of Education Review 6: 1-14.

1993. Why do different countries chose a different public/private mix of

education services? Journal of Human Resources 28: 531-92.

Kernerman, Gerald. 2005. Multicultural nationalism: civilizing difference, constituting community. Vancouver, BC: UBC Press.

Korpi, Walter. 1983. The Democratic Class Struggle. Boston: Routledge and Kegan Paul.

La Ferrara, Eliana. 2002. Self-Help Groups and Income Generation in the Informal Settlements of Nairobi. Journal of African Economics, 11: 61-89. . 2003. Ethnicity and Reciprocity: A Model of Credit Transactions in Ghana. American Economic Review 93: 1730-51.

Linos, Katerina, and Martin West. 2003. Self-interest, social beliefs, and attitudes to the redistribution. European Sociological Review 19: 393-409.

Luttmer, Erzo. 2001. Group Loyalty and the Taste for Redistribution. Journal of Political Economy 10): 500-28.

Martinez-Herrera, Eric. 2004. Liberal-Nationalist Theory, Political Confidence and Support for the Welfare State: Evidence from Britain. European University Institute SPS Working Papers. Mau, Steffen and Christoph Burkardt 2009. "Migration and welfare state solidarity in Western Europe.” Journal of European Social Policy 19: 213-229.

Mayda, Anna Maria. 2006. Who is Against Immigration? A Cross-Country Investigation of Individual Attitudes toward Immigrants. Review of Economics and Statistics 88: 510-30. Meltzer, Allan H., and Scott F. Richard. 1981. A Rational Theory of the Size of Government. Journal of Political Economy 89: 914-27. 
Miller, David. 1995. On Nationality. Oxford: Oxford University Press. 1998. The Left, the Nation-State and European Citizenship. Dissent Summer: 47-

51. 2006. Multiculturalism and the Welfare State: Theoretical Reflections, in Keith Banting and Will Kymlicka (2006), pp. 323-338.

OECD. 2008. Growing Unequal? Income Distribution and Poverty in OECD Countries. Paris: OECD.

Quadagno, Jill. 1988. The Transformation of Old Age Security: Class Politics in the American Welfare State. Chicago: University of Chicago Press.

Reich, Robert 1991. The Work of Nations: Preparing Ourselves for $21^{\text {st }}$ Century Capitalism. New York: Random House.

Romer, Thomas. 1975. Individual Welfare, Majority Voting and the Properties of a Linear Income Tax. Journal of Public Economic 14: 163-85.

Rorty, Richard. 1999. Achieving Our Country: Leftist Thought in Twentieth-Century America. Cambridge, Mass: Harvard University Press.

Shayo, Moses. 2009. A Model of Social Identity with an Application to Political Economy: Nation, Class and Redistribution. American Political Science Review 103: 147-74.

Sides, John, and Jack Citrin. 2007. European Opinion About Immigration: the Role of Identities, Interests and Information. British Journal of Political Science 37: 477-505.

Skocpol, Theda. 1991. Targeting Within Universalism: Politically Viable Policies to Combat Poverty in the United States, in Christopher Jencks and Paul Peterson, eds. The Urban Underclass. Washington, DC: Brookings. 
Sniderman, Paul M., and Louk Hagendorn. 2007. When Ways of Life Collide: Multiculturalism and its Discontents in the Netherlands. Princeton, NJ: Princeton University Press.

Soroka, Stuart N., John F. Helliwell, and Richard Johnston. 2007. Measuring and Modelling Interpersonal Trust, in Fiona Kay and Richard Johnston, eds. Social Capital, Diversity, and the Welfare State. Vancouver, BC: UBC Press, pp. 95-132.

Soroka, Stuart N., Richard Johnston, and Keith Banting. 2007a. Ethnicity, Trust, and the Welfare State, in Fiona Kay and Richard Johnston, eds., Social Capital, Diversity, and the Welfare State. Vancouver, BC: UBC Press, pp. 279-303. 2007b. The Ties that Bind: Social Diversity and Cohesion in Canada, in Keith Banting, Thomas Courchene and Leslie Seidle, eds., Belonging? Diversity, Recognition and Shared Citizenship in Canada. Montreal: Institute for Research on Public Policy, pp. 561-600. Soysal, Yasemin. 1994. Limits of Citizenship. Chicago: University of Chicago Press.

Stephens, John. 1979. The Transition from Capitalism to Socialism. Urbana: University of Illinois Press.

Svallors, Stefan. 1997. Worlds of Welfare and Attitudes to Redistribution: A Comparison of Eight Western Nations. European Sociological Review 13: 283-304. 2003. Welfare Regimes and Welfare Opinions: A Comparison of Eight Western Countries. Social Indicators Research 64: 495-520.

Swank, Duane. 2002. Global Capital, Political Institutions and Policy Change in Developed Welfare States. Cambridge: Cambridge University Press.

Tamir, Yael 1993. Liberal Nationalism. Princeton, N.J.: Princeton University Press. 
Taylor-Gooby, Peter. 2005. Is the Future American? Or, Can Left Politics Preserve European Welfare States from Erosion through Growing 'Racial' Diversity? Journal of Social Policy 34: $661-72$.

Uberoi, Varun. 2008. Do Policies of Multiculturalism Change National Identities? Political Quarterly 79: 404-17. 
Table 1. Models of Welfare State Support

\begin{tabular}{|c|c|c|c|c|c|c|c|c|c|}
\hline & \multicolumn{3}{|c|}{ Redistribution } & \multicolumn{3}{|c|}{ Health } & \multicolumn{3}{|c|}{ Pensions } \\
\hline & (1) & (2) & (3) & (1) & (2) & (3) & (1) & (2) & (3) \\
\hline Economic Position & $\begin{array}{c}-2.454^{\star \star \star} \\
(.543)\end{array}$ & $\begin{array}{c}-2.249^{\star \star \star} \\
(.586)\end{array}$ & $\begin{array}{c}-2.074^{\star \star \star} \\
(.526)\end{array}$ & $\begin{array}{c}-3.502^{\star \star \star} \\
(1.005)\end{array}$ & $\begin{array}{c}-3.350^{* \star} \\
(1.075)\end{array}$ & $\begin{array}{c}-3.524^{\star * \star} \\
(1.003)\end{array}$ & $\begin{array}{c}-1.331^{\star \star} \\
(.428)\end{array}$ & $\begin{array}{c}-1.511^{\star *} \\
(.470)\end{array}$ & $\begin{array}{c}-1.320^{\star \star} \\
(.428)\end{array}$ \\
\hline Identity & $\begin{array}{l}-.631^{*} \\
(.265)\end{array}$ & $\begin{array}{l}-.540 \\
(.285)\end{array}$ & $\begin{array}{l}-.508^{*} \\
(.257)\end{array}$ & $\begin{array}{l}-.067 \\
(.235)\end{array}$ & $\begin{array}{l}.045 \\
(.253)\end{array}$ & $\begin{array}{l}-.119 \\
(.235)\end{array}$ & $\begin{array}{l}.074 \\
(.116)\end{array}$ & $\begin{array}{l}.160 \\
(.130)\end{array}$ & $\begin{array}{l}.071 \\
(.116)\end{array}$ \\
\hline${ }^{*}$ Econ Position & $\begin{array}{c}1.688^{\star *} \\
(.625)\end{array}$ & $\begin{array}{l}1.338^{*} \\
(.671)\end{array}$ & $\begin{array}{l}1.268^{*} \\
(.605)\end{array}$ & $\begin{array}{l}3.077^{\star \star} \\
(1.166)\end{array}$ & $\begin{array}{c}1.484 \\
(1.257)\end{array}$ & $\begin{array}{l}3.203^{\star *} \\
(1.164)\end{array}$ & $\begin{array}{l}.379 \\
(.493)\end{array}$ & $\begin{array}{l}-.208 \\
(.546)\end{array}$ & $\begin{array}{l}.356 \\
(.493)\end{array}$ \\
\hline Interpersonal Trust & & $\begin{array}{c}.192 \\
(.174)\end{array}$ & & & $\begin{array}{l}-.076 \\
(.163)\end{array}$ & & & $\begin{array}{l}-.063 \\
(.084)\end{array}$ & \\
\hline${ }^{\star}$ Econ Position & & $\begin{array}{l}-.373 \\
(.409)\end{array}$ & & & $\begin{array}{l}.910 \\
(.835)\end{array}$ & & & $\begin{array}{l}.400 \\
(.339)\end{array}$ & \\
\hline Trust in Government & & $\begin{array}{l}-.263 \\
(.173)\end{array}$ & & & $\begin{array}{l}-.017 \\
(.162)\end{array}$ & & & $\begin{array}{l}-.125 \\
(.084)\end{array}$ & \\
\hline *Econ Position & & $\begin{array}{l}.859^{\star} \\
(.406)\end{array}$ & & & $\begin{array}{l}1.731^{*} \\
(.818)\end{array}$ & & & $\begin{array}{l}.942^{\star *} \\
(.343)\end{array}$ & \\
\hline Anti-Immigration & & & $\begin{array}{c}-.131^{\star \star \star} \\
(.009)\end{array}$ & & & $\begin{array}{c}-.071^{* \star *} \\
(.018)\end{array}$ & & & $\begin{array}{l}-.022 \\
(.014)\end{array}$ \\
\hline Constant & $\begin{array}{c}1.544^{\star \star *} \\
(.230)\end{array}$ & $\begin{array}{c}1.441^{* * *} \\
(.249)\end{array}$ & $\begin{array}{c}1.507^{\star \star \star} \\
(.223)\end{array}$ & $\begin{array}{c}1.033^{\star * *} \\
(.204)\end{array}$ & $\begin{array}{l}.967^{\star \star \star} \\
(.216)\end{array}$ & $\begin{array}{c}1.102^{\star \star \star} \\
(.204)\end{array}$ & $\begin{array}{l}.938^{* * *} \\
(.101)\end{array}$ & $\begin{array}{c}.960^{* * *} \\
(.112)\end{array}$ & $\begin{array}{l}.955^{\star \star \star} \\
(.101)\end{array}$ \\
\hline$\overline{R^{2} \text { adjusted }}$ & .050 & .062 & .110 & .047 & .077 & .052 & .067 & .071 & .067 \\
\hline RMSE & .204 & .204 & .198 & .385 & .379 & .384 & .309 & .310 & .309 \\
\hline $\mathrm{N}$ & 3147 & 3055 & 3145 & 3144 & 3052 & 3142 & 3147 & 3055 & 3145 \\
\hline
\end{tabular}

ESC 2nd wave, outside Quebec, non-visible minority, non-immigrant only. "Economic position" is based on a first-stage estimation using redistribution, health or pensions as the dependent variable. See Appendix Table $\mathrm{A} 1$ for first-stage estimations.

${ }^{*} p<0.05 ;{ }^{* *} p<0.01 ;{ }^{* *} p<0.001$. 
Table 2. Models of Identity, Trust, and Anti-Immigrant Sentiment

\begin{tabular}{lcccc}
\hline & Identity & $\begin{array}{c}\text { Interpersonal } \\
\text { Trust }\end{array}$ & $\begin{array}{c}\text { Trust in } \\
\text { Government }\end{array}$ & $\begin{array}{c}\text { Anti-Immigrant } \\
\text { Sentiment }\end{array}$ \\
\hline Economic Position & $.023^{*}$ & .021 & $.102^{* * *}$ & $2.882^{* *}$ \\
& $(.011)$ & $(.017)$ & $(.017)$ & $(1.047)$ \\
Identity & & $.289^{* * *}$ & $.523^{* * *}$ & .924 \\
& & $(.025)$ & $(.025)$ & $(.512)$ \\
* Econ Position & & & & $-3.181^{* *}$ \\
& & & & $(1.205)$ \\
Constant & $.842^{* * *}$ & $.429^{* * *}$ & $-.082^{* * *}$ & -.271 \\
& $(.007)$ & $(.023)$ & $(.023)$ & $(.445)$ \\
\hline $\mathrm{R}^{2}$ adjusted & .001 & .038 & .127 & .023 \\
$\mathrm{RMSE}$ & .140 & .204 & .202 & .394 \\
$\mathrm{~N}$ & 3427 & 3423 & 3311 & 3145 \\
\hline
\end{tabular}

ESC 2nd wave, outside Quebec, non-visible minority, non-immigrant only.

${ }^{*} \mathrm{p}<0.05 ;{ }^{* *} \mathrm{p}<0.01 ;{ }^{* * *} \mathrm{p}<0.001$. 
Figure 1.

Identification with Canada as a Mediator of the Economic Basis of Welfare State Support
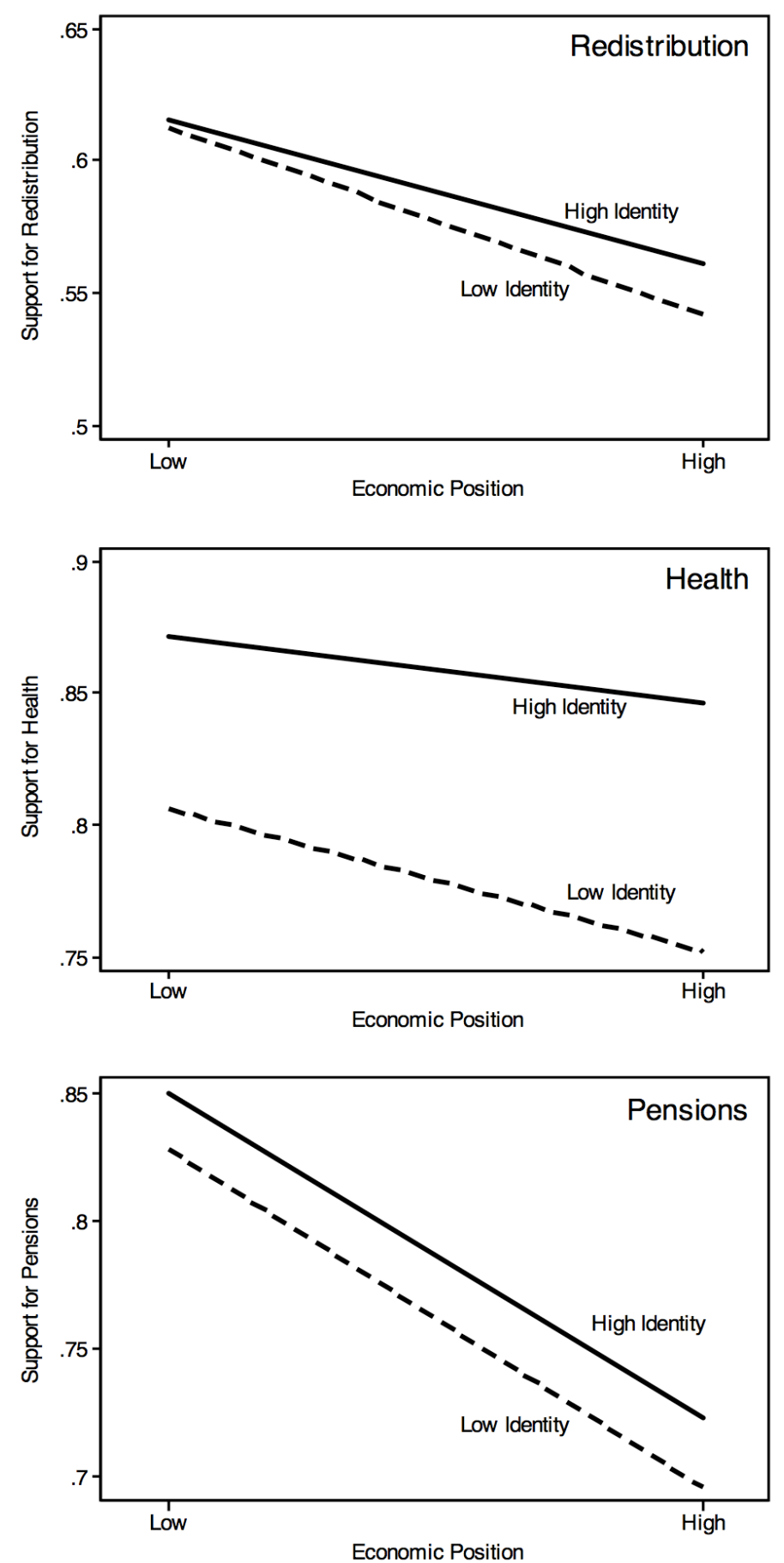

Note: White native-born non-Quebec residents. Results are based on simulations using Model 2 of Table 1. "Low" economic position and identity correspond to the in-sample 25th percentile of those variables; "High" economic position and identity correspond to the in-sample 75th percentile of those variables. 
Figure 2. Identification with Canada as a Mediator of the Economic Basis of Anti-Immigrant Sentiment

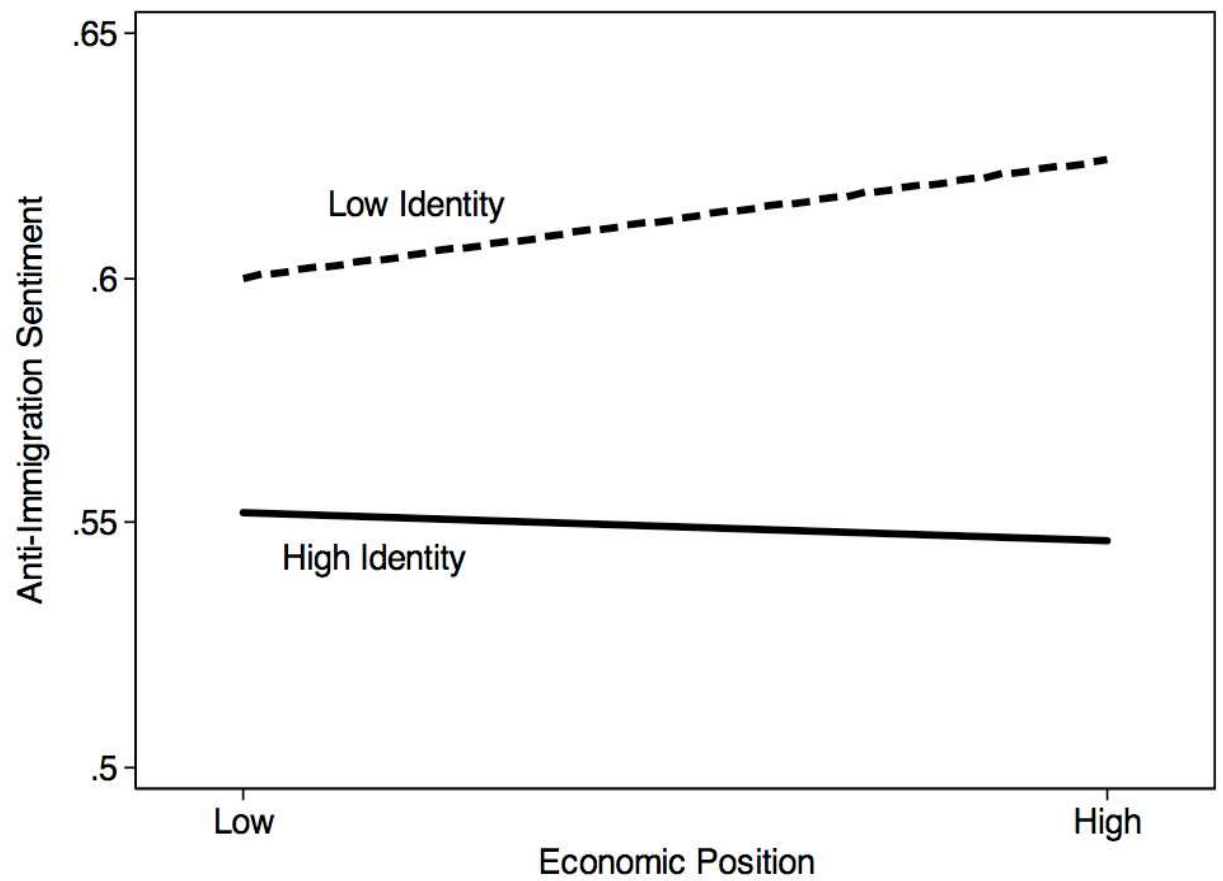

Note: White native-born non-Quebec residents. Results are based on simulations using Model 2 of Table 3. "Low" economic position and identity correspond to the insample 25th percentile of those variables; "High" economic position and identity correspond to the in-sample 75th percentile of those variables. 
Figure 3. Economic Position, Mediated by Identification with Canada and Anti-Immigration Sentiment, and Support for Redistribution
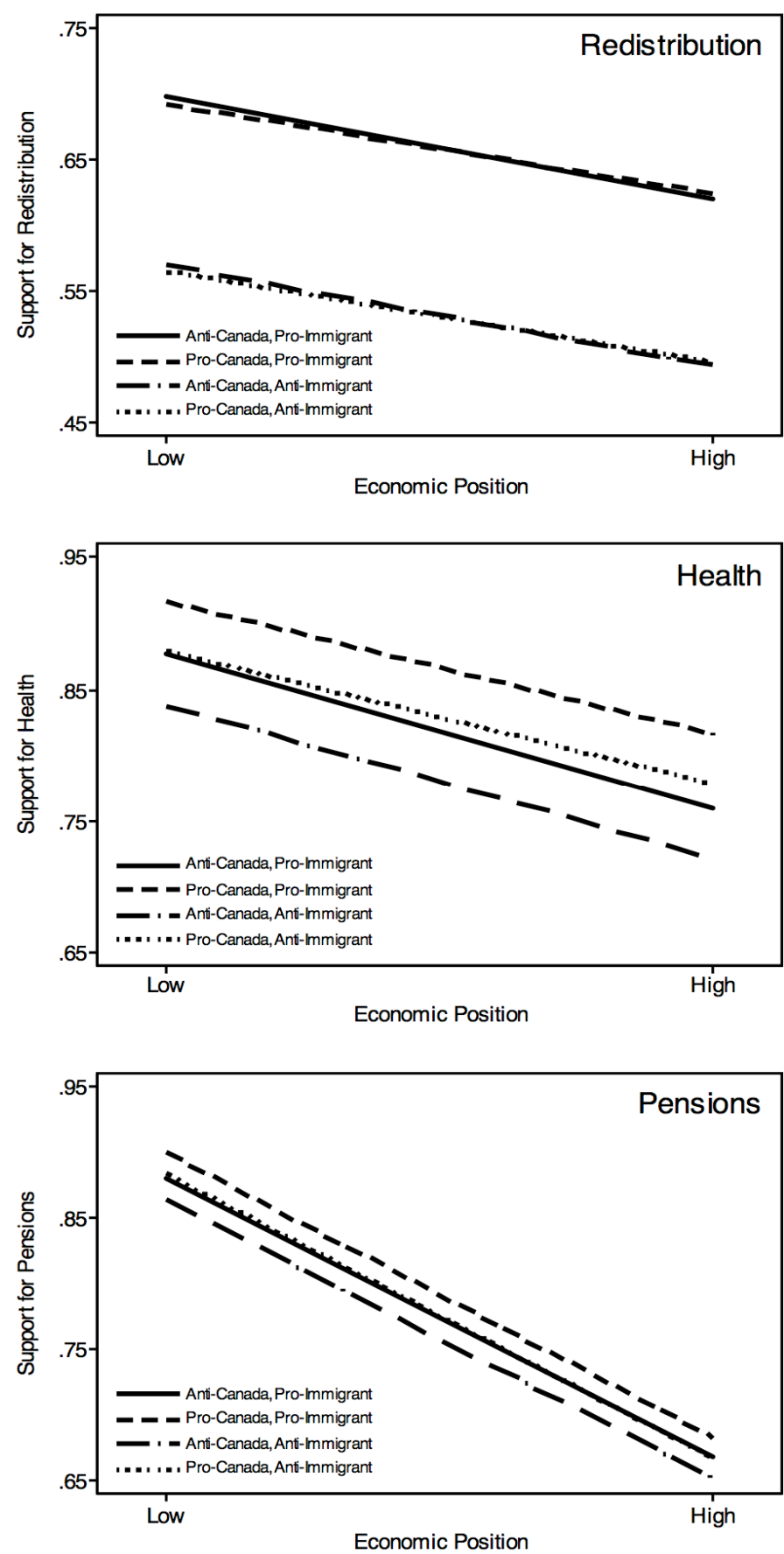

Note: White native-born non-Quebec residents. Results are based on simulations using Model 5 of Table 1. "Low" economic position and identity correspond to the insample 25th percentile of those variables; "High" economic position and identity correspond to the in-sample 75th percentile of those variables. 


\section{Appendix Table A1. First-stage Models of "Economic Position"}

\begin{tabular}{|c|c|c|c|}
\hline & Redistribution & Health & Pensions \\
\hline \multirow[t]{2}{*}{ Income } & $-.023^{* \star *}$ & .008 & $-.026^{\star *}$ \\
\hline & $(.006)$ & $(.011)$ & $(.009)$ \\
\hline \multirow[t]{2}{*}{ Union } & $.048^{* \star *}$ & .023 & $.045^{\star *}$ \\
\hline & $(.009)$ & $(.018)$ & $(.014)$ \\
\hline \multirow[t]{2}{*}{ Work Status: Unemployed } & .055 & -.062 & -.013 \\
\hline & $(.033)$ & $(.064)$ & $(.050)$ \\
\hline \multirow[t]{2}{*}{ Work Status: Other } & $.050^{\star \star \star}$ & -.023 & $.039^{*}$ \\
\hline & $(.011)$ & $(.020)$ & $(.016)$ \\
\hline \multirow[t]{2}{*}{ Economic Evaluations (Worse) } & $.023^{*}$ & $-.069^{* * *}$ & -.007 \\
\hline & $(.009)$ & $(.018)$ & $(.014)$ \\
\hline \multirow[t]{2}{*}{ Likelihood of Job Loss } & $.052^{* *}$ & -.007 & .043 \\
\hline & $(.016)$ & $(.030)$ & $(.024)$ \\
\hline \multirow[t]{2}{*}{ Female } & $.051^{* * *}$ & -.006 & $.046^{* * *}$ \\
\hline & $(.007)$ & $(.014)$ & $(.011)$ \\
\hline \multirow[t]{2}{*}{ Age: $30-49$} & .011 & $-.040^{*}$ & $.038^{*}$ \\
\hline & $(.010)$ & $(.019)$ & $(.015)$ \\
\hline \multirow[t]{2}{*}{ Age: $50-64$} & -.007 & $-.052^{*}$ & $.137^{\star * *}$ \\
\hline & $(.011)$ & $(.022)$ & $(.017)$ \\
\hline \multirow[t]{2}{*}{ Age: 65 and over } & $-.052^{\star \star \star}$ & -.040 & $.174^{\star * *}$ \\
\hline & $(.014)$ & $(.027)$ & $(.021)$ \\
\hline \multirow[t]{2}{*}{ Constant } & $.529^{\star \star \star}$ & $.857^{\star \star \star}$ & $.666^{\star * *}$ \\
\hline & $(.011)$ & $(.021)$ & $(.017)$ \\
\hline$\overline{R^{2} \text { adjusted }}$ & .042 & .008 & .060 \\
\hline RMSE & .205 & .393 & .311 \\
\hline $\mathrm{N}$ & 3147 & 3147 & 3147 \\
\hline
\end{tabular}

ESC 2nd wave, outside Quebec, non-visible minority, non-immigrant only.

${ }^{*} p<0.05 ;{ }^{* *} p<0.01 ;{ }^{* * *} p<0.001$. 
The Stockholm University

Linnaeus Center for

Integration Studies (SULCIS)

SULCIS is a multi-disciplinary research center focusing on migration and integration funded by a Linnaeus Grant from the Swedish Research Council (VR). SULCIS consists of affiliated researchers at the Department of Criminology, the Department of Economics, the Department of Human Geography, the Department of Sociology and the Swedish Institute for Social Research (SOFI). For more information, see our website: $\underline{w w w . s u . s e / s u l c i s}$

\title{
SULCIS Working Paper Series
}

\author{
2007:1 Arai, M \& Skogman Thoursie, P., "Giving Up Foreign \\ Names: An empirical Examination of Surname Change and \\ Earnings" \\ 2007:2 Szulkin, R. \& Jonsson, J.O., "Immigration, Ethnic Se- \\ gregation and Educational Outcomes: A Multilevel Anal- \\ ysis of Swedish Comprehensive Schools" \\ 2007:3 Nekby, L. \& Özcan, G., "Do Domestic Educations Even \\ Out the Playing Field? Ethnic Labor Market Gaps in \\ Sweden" \\ 2007:4 Nekby, L. \& Rödin, M., "Acculturation Identity and La- \\ bor Market Outcomes" \\ 2007:5 Lundborg, P., "Assimilation in Sweden: Wages, Employ- \\ ment and Work Income" \\ 2007:6 Nekby, L., Rödin, M. \& Özcan, G., "Acculturation Iden- \\ tity and Educational Attainmnet" \\ 2007:7 Bursell, M., "What's in a name? A field experiment \\ test for the existence of ethnic discrimination in the \\ hiring process" \\ 2007:8 Bygren, M. \& Szulkin, R., "Ethnic Environment during \\ Childhood and the Educational Attainment of Immigrant \\ Children in Sweden" \\ 2008:1 Hedberg, C., "Entrance, Exit and Exclusion: Labour \\ Market Flows of Foreign Born Adults in Swedish "Di- \\ vided Cities" \\ 2008:2 Arai, M, Bursell, M. \& Nekby, L. "Between Meritocracy \\ and Ethnic Discrimination: The Gender Difference" \\ 2008:3 Bunar, N., "Urban Schools in Sweden. Between Social \\ Predicaments, the Power of Stigma and Relational Di- \\ lemmas"
}


2008:4 Larsen, B. and Waisman G., "Who is Hurt by Discrimination?"

2008:5 Waisman, G. and Larsen, B., "Do Attitudes Towards Immigrants Matter?"

2009:1 Arai, M., Karlsson, J. and Lundholm, M. "On Fragile Grounds: A replication of "Are Muslim immigrants different in terms of cultural integration?"

2009:2 Arai, M., Karlsson, J. and Lundholm, M. "On Fragile Grounds: A replication of "Are Muslim immigrants different in terms of cultural integration?" Technical documentation.

2009:3 Bunar, N. "Can Multicultural Urban Schools in Sweden Survive Freedom of Choice Policy?"

2009:4 Andersson Joona, P and Nekby, L. "TIPping the Scales towards Greater Employment Chances? Evaluation of a Trial Introduction Program (TIP) for Newly-Arrived Immigrants based on Random Program Assignment - Mid Program Results."

2009:5 Andersson Joona, P and Nekby, L. "TIPping the Scales towards Greater Employment Chances? Evaluation of a Trial Introduction Program (TIP) for Newly-Arrived Immigrants based on Random Program Assignment"

2009:6 Arai, M., Besancenot, D., Huynh, K. and Skalli, A., "Children's First Names and Immigration Background in France"

2009:7 Çelikaksoy, A., Nekby, L. and Rashid, S., "Assortative Mating by Ethnic Background and Education in Sweden: The Role of Parental Composition on Partner Choice"

2009:8 Hedberg, C., "Intersections of Immigrant Status and Gender in the Swedish Entrepreneurial Landscape"

2009:9 Hällsten, M and Szulkin, R., "Families, neighborhoods, and the future: The transition to adulthood of children of native and immigrant origin in Sweden.

2009:10 Cerna, L., "Changes in Swedish Labour Immigration Policy: A Slight Revolution?"

2009:11 Andersson Joona, P. and Wadensjö, E., "Being employed by a co-national:

A cul-de-sac or a short cut to the main road of the labour market?

2009:12 Bursell, M. "Surname change and destigmatization strategies among Middle Eastern immigrants in Sweden"

2010:1 Gerdes, C., "Does Immigration Induce 'Native Flight' from Public Schools?

Evidence from a large scale voucher program"

2010:2 Bygren, M., "Unpacking the Causes of Ethnic Segregation across Workplaces" 
2010:3 Gerdes, C. and Wadensjö, E. "The impact of immigration on election outcomes in Danish municipalities"

2010:4 Nekby, L. "Same, Same but (Initially) Different? The Social Integration of Natives and Immigrants in Sweden"

2010:5 Akis, Y. and Kalaylioglu; M. "Turkish Associations in Metropolitan Stockholm: Organizational Differentiation and Socio-Political Participation of Turkish Immigrants"

2010:6 Hedberg, C. and Tammaru, T., "Neighbourhood Effects' and 'City Effects' Immigrants' Transition to Employment in Swedish Large City-Regions"

2010:7 Chiswick, B.R. and Miller, P.W., "Educational Mismatch: Are High-Skilled Immigrants Really Working at High-Skilled Jobs and the Price They Pay if They Aren't?"

2010:8 Chiswick, B.R. and Houseworth, C. A., "Ethnic Intermarriage among Immigrants: Human Capital and Assortative Mating"

2010:9 Chiswick, B.R. and Miller, P.W., "The "Negative" Assimilation of Immigrants: A Special Case"

2010:10 Niknami, S. "Intergenerational Transmission of Education among Immigrant Mothers and their Daughters in Sweden"

2010:11 Johnston, R., Banting, K., Kymlicka, W., and Soroka, S., "National Identity and Support for the Welfare State" 